\title{
Interventions to reduce household food insecurity: a synthesis of current concepts and approaches for Latin America
}

\author{
Intervenções para reduzir a insegurança alimentar: \\ uma síntese dos atuais conceitos e abordagens \\ para a América Latina
}

Donald Diego ROSE ${ }^{1}$

A B S T R A C T

Food insecurity has been documented in countries throughout the range of national incomes. Most Latin American countries, including Brazil, fall in the middle of this range. Although responses to problems of food insecurity need to be developed for specific contexts, valuable lessons for successful interventions can be learned from both low - and high-income countries. This article begins by describing a continuum of countrylevel food security contexts. The basic elements of food security, including food availability, access, and utilization, are reviewed as are more recent developments in the field, including livelihood analysis, vulnerability, and risk management strategies. A selection of public sector food security interventions is described that focus on improving agricultural production, increasing employment and household income, developing human capital, and distributing food. Recent international experiences and insights are used to develop themes for orientation of these types of food security interventions in Latin America. These include: the importance of planning relief efforts to be synergistic with long-run development; the tailoring of interventions to the needs of specific contexts; and the related expansion of information systems to support these activities. The article also describes the need to improve food security without leading to over-consumption, a problem of increasing concern in Latin America and elsewhere. Finally, development of local capacity through community-based participatory actions is suggested as a means for improving program outcomes as well as promoting human rights.

Indexing terms: Food security. Income. Nutrition Programmes and Policies. Vulnerability.

\section{R E S U M O}

A insegurança alimentar tem sido documentada em países de toda a gama de rendas nacionais, desde os países de mais baixa até os de mais alta renda. A maioria dos países latino-americanos, incluindo o Brasil, está

\footnotetext{
1 Tulane University, School of Public Health \& Tropical Medicine, Department of Community Health Sciences. 1440 Canal Street, TW-19, Suite \#2301, New Orleans, LA 70112, USA. E-mail: <diego@tulane.edu>.
} 
no meio deste espectro. Embora as ações direcionadas aos problemas de insegurança alimentar precisem ser desenvolvidas de acordo com contextos específicos, lições valiosas para o êxito das intervenções podem ser aprendidas das experiências dos países de baixa e de alta renda. Este artigo descreve a segurança alimentar nos diferentes contextos nacionais. Os elementos básicos de segurança alimentar, incluindo a disponibilidade de alimentos, o acesso e a utilização são revisados, assim como os desenvolvimentos mais recentes na área, incluindo análises de subsistência, vulnerabilidade e estratégias de gestão de risco. É apresentada uma seleção das intervenções do sector público de segurança alimentar, que se destinam a melhorar a produção agrícola, a aumentar o nível de emprego e da renda familiar, ao desenvolvimento do capital humano e à distribuição de alimentos. Experiências internacionais recentes são utilizadas com o intuito de desenvolver temas para orientação desses tipos de intervenções de segurança alimentar na América Latina. Dentre as quais, se inclui: a importância de que os projetos de auxílio estejam em sinergia com o desenvolvimento em longo prazo, a adaptação das intervenções às necessidades dos contextos específicos e a expansão dos sistemas de informação para apoiar estas atividades. 0 artigo também descreve a necessidade de melhorar a segurança alimentar sem levar a um excesso de consumo, um problema cada vez mais preocupante, tanto na América Latina como em outros lugares. Finalmente, o desenvolvimento das capacidades locais a partir de ações comunitárias participativas é sugerido, como um meio para melhorar os resultados dos programas assim como assegurar os direitos humanos.

Termos de indexação: Segurança alimentar e nutricional. Renda. Programas e políticas de nutrição e alimentação. Vulnerabilidade.

\section{IN TRO D U C TIO N}

Like poverty, food insecurity has been documented in countries throughout the range of national incomes. This is striking, in part, because dietary energy supplies are so much more plentiful in the richest countries. Aggregate data from the UN Food and Agriculture Organization show that food supplies provided 3,770 calories per person per day in the United States (US), about 2.3 times the comparable figure for Burundi in the period from 2001 to $2003^{1}$. The existence of food insecurity in the U.S. and other countries with per capita energy supplies well over biological needs is due, in part, to an unequal distribution of resources. In shock-prone countries of Sub-Saharan Africa, like Burundi, it is food availability, as well as access to food, that can be problematic.

Food security interventions need to be tailored to specific contexts and problems. However valuable insights can be gained by studying the experiences of the food security response in countries throughout the range of national incomes. Latin American countries, for the most part being in the middle of this range, can benefit from experiences of countries at both ends of it.

This article provides a review of current approaches underlying improvements in household food insecurity. It draws on experiences and insights throughout the world with references from searches in academic databases, such as EconLit and Agricola, websites of international and other agencies, such as the World Bank and the Food and Agriculture Organization (FAO) and the author's own experience. Selection for inclusion was based on relevance to the themes developed here. The article begins with a brief discussion of the range of food security contexts that are found across the income spectrum. The subsequent section outlines recent advances in the response to food insecurity. A typology illustrative of the breadth of public-sector interventions is then described. A final section outlines four key themes that may be useful for policymakers and program administrators working in Latin America.

\section{A continuum of contexts}

Table 1 displays income, food supply, and nutrition indicators of selected countries in Latin America and elsewhere. The table is meant to provide an illustration of the range of food security contexts found across the world, rather than a comprehensive statistical picture. The countries are sorted by per capita gross national income; included is the World Bank classification of 
countries by their status on this indicator $r^{2}$. Most Latin American countries are in the lower middle or upper middle income categories.

Many African countries are found in the low income category, where available supplies of food energy are often less than 2,200 calories per capita per day. FAO's undernourishment indicator, which combines this food supply information with other distributional and requirement data, provides an estimate of the percent of the population that does not meet their energy needs ${ }^{1}$. The low-income African countries in Table 1 have rates above 30\%, whereas most Latin countries have rates below $25 \%$. The percent of the population living on $\$ 1$ per day or less, a measure of extreme poverty developed by the World Bank, provides additional information on the problem of food access ${ }^{1}$. Data from the World Health Organization (WHO) on the percentage of children under 5 that are low weight-for-age ${ }^{3}$ give insights into the magnitude of food access and utilization problems in these countries, since anthropometric outcomes are influenced by diet as well as illness.

A number of generalizations can be made from these data. For most Latin American countries, food insecurity is less a problem of availability and more a question of access and utilization. For many African countries food availability, conditioned by

Table 1. A continuum of food security contexts: Income, food supply, and nutritional indicators of selected countries in Latin America and elsewhere.

\begin{tabular}{|c|c|c|c|c|c|c|c|}
\hline Country & $\begin{array}{l}\text { World Bank } \\
\text { classification of } \\
\text { economy }\end{array}$ & $\begin{array}{l}\text { Gross National } \\
\text { Income per } \\
\text { capita (US\$) }\end{array}$ & $\begin{array}{l}\text { Dietary energy } \\
\text { supply per capita } \\
\text { (kilo-calories) }\end{array}$ & $\begin{array}{c}\text { Percent } \\
\text { under-nourished }\end{array}$ & $\begin{array}{c}\text { Percent living } \\
\text { on less than } \\
\$ 1 / \text { day }\end{array}$ & $\begin{array}{c}\text { Percent of } \\
\text { children under- } \\
\text { weight-for-age }\end{array}$ & $\begin{array}{c}\text { Percent of } \\
\text { adult females } \\
\text { obese }\end{array}$ \\
\hline Burundi & Low & 100 & 1,640 & 67 & 54.6 & 38.9 & \\
\hline Ethiopia & Low & 160 & 1,860 & 46 & 23 & 34.6 & 0.3 \\
\hline Malawi & Low & 160 & 2,140 & 34 & 41.7 & 18.4 & 2.1 \\
\hline Mozambique & Low & 310 & 2,070 & 45 & 37.9 & 21.2 & 3.9 \\
\hline Haiti & Low & 450 & 2,090 & 47 & & 13.9 & 7.8 \\
\hline Kenya & Low & 540 & 2,150 & 31 & 22.8 & 16.5 & 6.3 \\
\hline India & Low & 730 & 2,440 & 20 & 34.7 & 44.4 & 0.6 \\
\hline Nicaragua & Lower middle & 950 & 2,290 & 27 & 45.1 & 7.8 & 18.0 \\
\hline Bolivia & Lower middle & 1,010 & 2,220 & 23 & 14.4 & 5.9 & 15.1 \\
\hline Honduras & Lower middle & 1,120 & 2,360 & 22 & 20.7 & 8.6 & \\
\hline Egypt & Lower middle & 1,260 & 3,350 & 3 & 3.1 & 5.4 & 33.0 \\
\hline China & Lower middle & 1,740 & 2,940 & 12 & & 6.1 & 3.4 \\
\hline Colombia & Lower middle & 2,290 & 2,580 & 14 & 8.2 & 5.1 & 16.6 \\
\hline Guatemala & Lower middle & 2,400 & 2,210 & 23 & 16 & 17.7 & 12.2 \\
\hline Peru & Lower middle & 2,650 & 2,570 & 12 & 18.1 & 5.2 & 19.9 \\
\hline Jamaica & Lower middle & 3,390 & 2,680 & 10 & $<2$ & 3.1 & \\
\hline Brazil & Lower middle & 3,550 & 3,060 & 8 & 8.2 & 3.7 & 13.1 \\
\hline Argentina & Upper middle & 4,470 & 2,980 & $<2.5$ & 3.3 & 2.3 & \\
\hline Costa Rica & Upper middle & 4,700 & 2,850 & 4 & $<2$ & & \\
\hline South Africa & Upper middle & 4,770 & 2,940 & $<2.5$ & 10.7 & 9.6 & 30.1 \\
\hline Venezuela & Upper middle & 4,820 & 2,350 & 18 & 14.3 & 4.8 & \\
\hline Chile & Upper middle & 5,870 & 2,860 & 4 & $<2$ & 0.8 & 25.0 \\
\hline M exico & Upper middle & 7,310 & 3,180 & 5 & 9.9 & 3.4 & 28.1 \\
\hline Spain & High & 25,250 & 3,410 & $<2.5$ & & & 13.5 \\
\hline Canada & High & 32,590 & 3,590 & $<2.5$ & & & 13.9 \\
\hline Japan & High & 38,950 & 2,770 & $<2.5$ & & & 3.3 \\
\hline USA & High & 43,560 & 3,770 & $<2.5$ & & 1.1 & 33.2 \\
\hline
\end{tabular}

Notes: Data from World Bank, FAO, WHO ${ }^{1-3}$. Gross national income per capita is from 2005. Energy availability and the FAO undernourishment indicator are estimates for the period from 2001-2003. Percent with consumption expenditures less than $\$ 1$ per day is World Bank's extreme poverty indicator; data are from 2003. Underweight prevalence is for children less than 5 years; data are the latest available. Obesity prevalence is for adult women older than 15 years with body mass index greater than 30; data are latest available. 
difficult climates and fragile economies, is still a serious concern as are issues of access and utilization. At the other end of the spectrum, high-income countries have problems of overconsumption, and obesity affects a sizable portion of their populations.

\section{Recent advances underlying food security interventions}

The most commonly-used definition of food security - "when all people, at all times, have physical and economic access to sufficient, safe and nutritious foods to meet their dietary needs and food preferences for an active and healthy life" - comes from the 1996 World Food Summit'. At the time, many researchers, policymakers, and program managers distinguished food availability, food access, and food utilization as the three key components of food security.

Brown \& Gentilini ${ }^{5}$ have traced the history of the food security field with respect to these components. In the 1970s, the Soviet grain shortfall, spikes in oil prices, and the 1974 World Food Conference prompted much of the early work on food security to focus on national and international food supplies at an aggregate level. Access became the key theme for the 1980s, prompted by the work of Nobel-prize winning economist Amartya Sen and later reinforced by a key World Bank study ${ }^{6,7}$. Sen linked severe food insecurity, or famines, to poverty, and the inability of households to command sufficient resources for acquiring food. By the 1990s, the focus included a concern with diet quality and the links of household food insecurity to nutritional outcomes influenced by care, sanitation and health services.

Since the 1980s, when the focus of food insecurity shifted to the household level, it has been clear that food insecurity can be either chronic or transitory ${ }^{7}$. Households suffering long-term inadequate access to food, most commonly linked to poverty, can be considered chronically food insecure. This is distinguished from transitory food insecurity which often occurs in conjunction with agricultural cycles, for example when households suffer from a "hungry" season. Transitory food insecurity can also be caused by an unpredicted shock, such as a drought or political conflict. The dichotomy between the two forms of food insecurity is not always clear-cut. An inability to mitigate the effects of a shock or of annual cycles of food insecurity can precipitate long-term chronic food insecurity. Alternatively, some intervention strategies seek to reduce the cyclical lows in agriculture or other income sources to reduce chronic household poverty or food insecurity ${ }^{5,8}$.

A better understanding of this dynamic nature of food insecurity has been a hallmark of food security planning and programming over the last $10-15$ years. Planners and programmers have focused on three aspects of household food security that have become central to the field. These include an emphasis on livelihoods, a better understanding of vulnerability, and the orientation of strategies to assist households manage the different types of risks that they face.

\section{Livelihood analysis}

The repeated nature of weather-based emergencies in Africa has focused the food security community on understanding the specific nature of a household's subsistence so that relief efforts can be timely and more effective in the short-run as well as supportive of a household's long-term sustainability. Although the importance of household livelihoods to economic well-being and food security outcomes has been present in the literature at least since the late $1980 \mathrm{~s}^{9,10}$, the incorporation of the concept into food security planning and intervention gained prominence in the late 1990 s and particularly in the early 2000 s. The Famine and Early Warning System (FEWS) livelihood framew ork ${ }^{11}$, Save the Children's Household Economy Approach ${ }^{12}$, and the World Food Program's Emergency Food Security Assessment Framew ork ${ }^{13}$ all incorporate livelihood approaches into their modeling of how households respond to shocks. 
At its most basic, a livelihood is a household's means of support or subsistence. A more comprehensive articulation of livelihood is "a household's capabilities, assets and activities required to secure basic needs - food, shelter, health, education, and income"13. Most poor households in developing countries support themselves with a portfolio of economic activities, such as: production of staple food crops, production of cash crops, small livestock, fruit trees, farm or non-farm employment, fishing or hunting, artisanal sales, etc. Understanding the percentage contribution of each of these activities to a household's income or food consumption in a non-crisis economy provides insights on the types of interventions that are needed, and their required magnitude when particular shocks occur.

A household's assets whether they be in the form of physical capital (e.g., land, farm machinery), financial capital (e.g., savings account), or human capital (e.g., education and health of household members) are of central importance to the livelihood approach. A household's ability to generate income is based on these assets. Thus, a key concern for those responding to problems of food insecurity is to facilitate the maintenance of a household's assets after a food security shock as well as the continued buildup of those assets when times improve. The stronger the position of a household with respect to its assets, the better it will be able to face a difficult situation in the future ${ }^{14,15}$.

For much of Latin America, food insecurity is a problem of access rooted in poverty. Thus, a better understanding of a household's economic situation and responses directed at specific needs are likely to have a positive impact on food security. In fact, livelihoods are so central to food insecurity outcomes and overall household well-being that the term "livelihood security" has gained prominence. This implies adequate stocks and flows of food and cash to meet basic needs; secure ownership of, or access to, resources and incomeearning activities to offset risk and ease shocks; and maintenance or enhancement of resource productivity on a long-term basis ${ }^{10}$.

\section{Household vulnerability}

Vulnerability, for those concerned with food security, is the probability of an acute decline in food access or consumption due to hazards in the physical or social environment. Typical hazards include weather disturbances, such as drought, or man-made disturbances, such as civil war or extreme price fluctuations. The recent literature on this relates a household's vulnerability to two specific functions: (1) exposure to a hazard (or, shock); and (2) a household's ability to cope with it (or, susceptibility to a livelihood threat) ${ }^{16,17}$.

Nutritionists will recognize these concepts by considering the situation of small children. Diarrheal illness caused by exposure to unsanitary food is much worse for a child whose reserves are already compromised. Vulnerability is related to both the situation (living in unsanitary conditions) which creates the risk as well as the current nutritional status of the child. Addressing vulnerability of small children, then, calls for reducing risks by improving the sanitary conditions of the household as well as reducing the effects of a risky event (e.g. intestinal infection) by building up the reserves, or nutritional status, of the child.

The analogy to household food insecurity and vulnerability is straightforward. The physical, political, economic, and social environments in which a household lives condition the riskiness of a particular event. Parts of Sub-Saharan Africa are more prone to shocks because of climactic conditions. In addition, a drought will have very different consequences for a household that lives in a remote area with weak food markets than a similar household living close to well-functioning markets. The drought-related food production shortfalls in Southern Africa were much larger in 1991-92 than in 2001-2, yet the consequences were more severe in the latter event, in part, because changes in government marketing policies left food prices more volatile ${ }^{15}$. Just as a household's larger environment conditions its exposure, a household's susceptibility - that is, the strength and 
diversity of its livelihood - conditions how well it will respond to a particular hazard.

\section{Risk management strategies}

The interplay between livelihoods and vulnerability has led food security programmers to focus on three aspects of how households deal with risk and to develop intervention strategies based on these. Specifically, attention has been paid to strengthening a household's or community's ability: (1) to prevent a shock, or negative event, from occurring; (2) to mitigate, or lessen, the effects of a shock that might occur; and (3) to cope with a problem once it has happened $8,18,19$.

Prevention strategies seek to reduce the likelihood of an adverse event from occurring ${ }^{8,18}$. Many of these strategies can be thought of as long-term development approaches. Improvements in rural infrastructure, such as roads, irrigation systems, storage facilities, and markets can reduce the possibility that a year with low rainfall can turn into an acute shortfall in food availability. While many prevention strategies are broad-based public efforts, there are many small-scale community and household measures. Efforts to increase household incomes or to develop more secure income sources would allow households to purchase foods in the event that unfavorable weather affected their own household production. Ultimately, improving the asset-base of poor households, including long-range investment in the health and education of children (i.e., human capital), can assist households to grow their way out of poverty and food insecurity.

M itigation strategies seek to minimize the potential impact of a hazardous event that may occur. Strategies that develop diverse sources of income for a household can allow it to respond better to particular shocks ${ }^{19}$. The planting of drought-resistant crops (e.g., cassava or manioc) can reduce the shortfall that a household might experience in year of low rainfall. Employment in non-agricultural activities can have a similar effect. Although there is some overlap betw een mitigation and prevention strategies, both types of approaches are known as 'ex ante,' in that they are implemented before a shock takes place.

Coping strategies are 'ex post' measures in that they seek to reduce the impact of a negative event once it has happened ${ }^{18}$. Strategies in this realm - usually referred to as relief, emergency response, or safety net approaches - can include direct assistance to increase a household's access to food, either through supplemental foods or income transfers. Not only does this assistance have a direct impact on a household's well-being, it helps to preserve its assets and thus it's potential for long-term food security. For example, selling off livestock or eating next year's seed to meet immediate food needs both jeopardize the future earning power of the household. Pulling children out of school to help with household labor needs reduces human capital and can have a similar effect.

\section{An illustrative typology of food security interventions}

This section presents a brief description of various food security interventions which have been used around the world. There are many ways to categorize food security interventions and most interventions cut across multiple categories. How ever, for purposes of this discussion, it is useful to organize interventions into four groups: programs to increase agricultural production; employment and income distribution programs; interventions to increase human capital; and foodbased distribution programs. Table 2 summarizes selected interventions from these groups.

Left out of this discussion are interventions at both the macro and micro ends of the spectrum. Macro-economic policy interventions (e.g., trade policies, price stabilization efforts, etc.) can affect food security outcomes by increasing overall income growth, or by affecting food prices within a country ${ }^{20}$. Interventions addressing the important issues of governance, including transparent legal systems, ethnic conflicts, and other sources of internal strife are important for 
preventing crises that lead to food insecurity ${ }^{19,21}$. Micronutrient interventions, such as food fortification and nutrient supplementations can have important affects on improving micronutrient outcomes, which can in turn, affect food utilization by reducing illness ${ }^{22}$. These are all essential issues for food security outcomes, but beyond the scope of this paper.

\section{Agricultural production}

Gains in agricultural production, long associated with making more food available for a population, continue to be an important means for accomplishing the Millennium Development Goal of reducing poverty and hunger, especially when directed at small producers. Although this

Table 2. A typology illustrative of selected food security interventions.

\begin{tabular}{|c|c|c|c|c|c|c|}
\hline \multirow[t]{2}{*}{ Type of intervention } & \multirow[t]{2}{*}{ Description of intervention } & $\begin{array}{l}\text { Food security } \\
\text { dimension }\end{array}$ & $\mathrm{ma}$ & $\begin{array}{l}\text { Risk } \\
\text { lagem }\end{array}$ & ent & \multirow{2}{*}{$\begin{array}{c}\text { Applied example } \\
\text { with citations }\end{array}$} \\
\hline & & AVL ACC UTL & PRE & MIT & COP & \\
\hline
\end{tabular}

\begin{tabular}{|c|c|c|c|c|c|c|c|c|}
\hline \multicolumn{9}{|c|}{ Agricultural production } \\
\hline Seeds and tools & $\begin{array}{l}\text { Short-term distribution of inputs after } \\
\text { shock to rehabilitate small-farm sector }\end{array}$ & $\dot{\varepsilon}$ & $\dot{2}$ & & & $\dot{\imath}$ & $i$ & Honduras 25 \\
\hline $\begin{array}{l}\text { Agricultural research } \& \\
\text { extension }\end{array}$ & $\begin{array}{l}\text { Development of new local crop varieties } \\
\text { and farmer education on how they } \\
\text { can be grown }\end{array}$ & $\dot{\varepsilon}$ & $\dot{i}$ & & $\dot{c}$ & $i$ & & $\begin{array}{l}\text { Extensa-Honduras }{ }^{38} \\
\text { M ozambique }^{26}\end{array}$ \\
\hline Cash transfers & $\begin{array}{l}\text { Direct purchases from small farmers to } \\
\text { increase rural incomes or payments to } \\
\text { producers in specific sectors to address } \\
\text { income shocks due to trade adjustments. }\end{array}$ & i & $i$ & & & $\dot{\imath}$ & $i$ & $\begin{array}{l}\text { PAA-Brazil|27,28 } \\
\text { Procampo-M exico }{ }^{29}\end{array}$ \\
\hline \multicolumn{9}{|c|}{ Employment and income } \\
\hline $\begin{array}{l}\text { Food-for-Work or } \\
\text { Cash-for-Work }\end{array}$ & $\begin{array}{l}\text { Food or cash payments in exchange } \\
\text { for labor on public works projects }\end{array}$ & & ¿ & & ¿ & $\dot{\varepsilon}$ & $i$ & $\begin{array}{l}\text { Somalia }{ }^{45} ; \\
\text { Poder-Honduras }\end{array}$ \\
\hline $\begin{array}{l}\text { Micro-credit and } \\
\text { micro-enterprise } \\
\text { development }\end{array}$ & $\begin{array}{l}\text { Facilitation of small business } \\
\text { development through credit-provision } \\
\text { and training in specific business skills } \\
\text { man Capital }\end{array}$ & & $\dot{\imath}$ & & $\dot{c}$ & $i$ & & $\begin{array}{l}\text { Grameen } \\
\text { Bank-Bangladesh, } \\
\text { Sagarpa-M exico, } \\
\text { CrediAmigo-Brazil }^{32,33}\end{array}$ \\
\hline Conditional cash transfers & $\begin{array}{l}\text { Cash payments, typically to women } \\
\text { heads of household, in exchange for } \\
\text { children's attendance in school or at } \\
\text { health clinics }\end{array}$ & & $\dot{i}$ & $\dot{\varepsilon}$ & $\dot{\varepsilon}$ & $i$ & $i$ & $\begin{array}{l}\text { Progresa/O portunida- } \\
\text { des-M exico }{ }^{34} ; \\
\text { RPS-Nicaragua }^{35} ; \\
\text { Bolsa Família-Brazil2 }\end{array}$ \\
\hline Service fee waivers & $\begin{array}{l}\text { Waiving of fees for school or heath } \\
\text { services }\end{array}$ & & & $\dot{2}$ & ¿ & & & El Salvador ${ }^{37}$ \\
\hline Nutrition education & $\begin{array}{l}\text { Education on optimal dietary and/or } \\
\text { sanitary practices. }\end{array}$ & & & ¿ & $\dot{i}$ & $i$ & & Mozambique $^{28} ;$ USA $^{39}$ \\
\hline \multicolumn{9}{|c|}{ Food-Based Distributions } \\
\hline $\mathrm{MCH}$ Feeding & $\begin{array}{l}\text { Food distribution to women, infants, } \\
\text { or children at maternal and child health } \\
\text { clinics, often combined with nutrition } \\
\text { education. }\end{array}$ & & $i$ & ¿ & ¿ & ¿ & ¿ & $\begin{array}{l}\text { Hogasa-Honduras }^{38} \\
\text { WIC-USA }\end{array}$ \\
\hline School Feeding & $\begin{array}{l}\text { Distribution of meals at schools or food } \\
\text { rations to households that send their } \\
\text { children to school }\end{array}$ & & ¿ & $\varepsilon$ & ¿ & ¿ & ¿ & Jamaica ${ }^{41} ;$ USA $^{42}$, Brazil ${ }^{36}$ \\
\hline Food stamps or vouchers & $\begin{array}{l}\text { Distribution of coupons or stamps that } \\
\text { can be used to purchase foods in local } \\
\text { markets }\end{array}$ & & $\dot{i}$ & & & $\dot{\imath}$ & $i$ & Sri Lanka ${ }^{30} ;$ USA $^{43}$ \\
\hline Emergency Feeding & $\begin{array}{l}\text { Short-term food distributions targeted } \\
\text { to vulnerable groups often in response } \\
\text { to a shock, and sometimes combined } \\
\text { with short-term sanitation and health } \\
\text { services. }\end{array}$ & & $i$ & ¿ & & & $i$ & Brazil $^{28}$, Ethiopia ${ }^{42}$ \\
\hline
\end{tabular}

Notes: Food security dimension refers to whether the intervention impacts availability (AVL), access (ACC), or utilization (UTL). Risk management refers to whether the intervention addresses prevention (PRE), mitigation (MIT), or coping (COP) with risks. See text for details. 
is likely to be a strategy of more importance in Africa and Asia, where rural populations are relatively larger and where land is less unequally distributed than in some parts of Latin America, agriculture plays a key role in rural economies, and economic growth and poverty reduction are not likely to be achieved without improvements in agricultural production ${ }^{23}$.

There are various interventions that have been used to increase agricultural production. Perhaps one of the most common interventions to be used in situations after a climactic shock is the distribution of seeds and tools to low-income farmers in an affected area ${ }^{24}$. Depending on the timing of the shock, and the quickness of the distribution, this intervention has the potential to mitigate some of the consequences of a weather shock by allowing farm households who have lost their crops to return to gainful production. Obviously this will only work in situations where households have access to their land, which given some shocks (eg, hurricane-induced mudslides in Central America) may also require temporary housing to be useful25. Agricultural research and extension can play an important role in increasing the development and adoption of new crops with improved yields. This strategy was at the root of the green revolution of the 1970s. Recent approaches have focused on developing crops for small-holders and improving nutritional characteristics. A program in M ozambique that integrated improved varieties of orange flesh sw eet potatoes with extension and nutrition education demonstrated increased yields as well as improved vitamin A status of children ${ }^{26}$. Direct purchases of food crops can increase the incomes of small farmers and provide foods for subsequent use in government nutrition programs, as it has in Brazil's Food Acquisition Program $(\text { PAA })^{27,28}$. Direct payments to farmers in sectors affected by liberalized trade agreements can cushion the income shock that might otherwise have occurred from competition from more efficient producers. Mexico's Procampo program was developed to do this in response to the NAFTA trade agreements ${ }^{29}$.

\section{Employment and income generation}

Because of the central role that livelihoods play in food security outcomes, programs to increase or to develop alternative sources of income, whether through employment or small business development, are important in this area. Food-for-w ork or cash-for-w ork are two such types of interventions that are often used in areas of acute or chronic food insecurity. In areas suffering dramatic shortfalls in food availability and where market systems are not working, distribution of food in return for labor on public w orks (e.g. roads, schools) can be useful for assisting households cope with immediate food deficits as well as developing community infrastructure that may cushion against future shocks ${ }^{5,30}$. Cash-for-w ork is likely a better alternative where food markets are functioning and food price inflation is not of concern $^{24,31}$. Much has been written about the success of micro-credit programs in fostering livelihood diversification and income growth. Nobel-prize winning Yosuf Grameen pioneered the Grameen Bank which has assisted millions of micro-enterprises in Bangladesh through small loans to purchase needed equipment (e.g. sewing machine), livestock, or other physical assets ${ }^{32,33}$. The programs are often integrated with social and educational components to assist in start-up of new businesses. Analogous programs are in operation in many countries including Mexico (SAGARPA) and Brazil (CrediAmigo) ${ }^{33}$.

\section{Human capital development}

Programs that develop the skills, education, and health of individuals, so-called human capital development, allow them to seek better employment opportunities and to fulfill their earning potential. This objective underlies a series of programs known as conditional cash transfers in Latin America. M exico's Progresa/Oportunidades ${ }^{34}$, Nicaragua's Red de Proteccion Social ${ }^{35}$, and Brazil's Bolsa Família ${ }^{36}$ all provide direct payments to lowincome women in exchange for attendance of 
their children in schools and health clinics. The payments have been show $n$ to increase access to food in the short-run and have the potential to reduce long-term poverty and food insecurity. Service fee waivers are also used to encourage attendance of children at schools or health clinics by eliminating customary payments that households would have to make at these facilities, an intervention that has been attempted recently in El Salvador ${ }^{37}$. Nutrition education, often integrated with other interventions, such as food distributions, can improve the knowledge and practices of meal preparers with regard to infant feeding, food selection, and sanitation practices ${ }^{38}$ and may be useful for promoting healthy food choices in environments where excess consumption is of concern ${ }^{39}$.

\section{Food-based assistance}

Nutritionists are most likely to be familiar with food-based distributions that are targeted to those in need and can assist households cope with immediate shocks to a household's food security as well as mitigate against long-term affects. Pregnant women, infants, and children are often targeted to receive supplemental food through maternal and child health clinics since their increased nutritional needs make them more vulnerable to shocks with nutritional insults having long-term consequences ${ }^{30}$. There are many examples of these programs throughout the developing world. Interestingly, this type of intervention has been adopted in high income countries - for example the Special Supplemental Nutrition Program for Women, Infants, and Children (WIC) in the U.S. - as a form of social protection, and has been shown to improve birth outcomes and reduce hospital costs due to a reduction in "low-birth weight babies ${ }^{40}$. School feeding programs deliver supplemental food to children in the form of meals or to their households in the form of take-home rations ${ }^{36}$. These programs have been shown to increase attendance and improve learning or dietary outcomes in various countries $30,41,42$. Food stamps or voucher programs are useful for ameliorating problems of short-run food insecurity. The administrative burden of these types of programs is sizable, but they have the advantage of offering participants more flexibility than direct food distributions as well as support to food marketing systems ${ }^{43}$. Emergency food programs are used in Brazil and other places to deliver food baskets to vulnerable groups ${ }^{28}$. Emergency feeding has been used in Ethiopia, as it is throughout the world, to deliver food to populations affected by immediate crises due to natural disaster or conflict ${ }^{44}$.

\section{Key themes for interventions in Latin America}

This section describes four themes that are useful for the orientation of food security interventions in Latin America. These include: connecting relief to development; developing interventions to meet problems in specific contexts; addressing over-consumption at the same time as food insecurity; and enhancing community-based participatory actions.

\section{Connect relief to development}

Although most Latin American countries are in much better overall economic conditions and suffer from far fewer food security hazards than many shock-prone, low-income countries in Sub-Saharan Africa, the region is not without serious climatologic, political, and economic shocks. Hurricanes and flooding in Honduras and Guatemala, drought in the Brazilian Amazon region, political strife in Haiti, and economic shocks in Mexico, Argentina, and various Central America countries have all affected the livelihoods, and thus food security status, of the region's poorest households. Furthermore, long-term climatic changes are making extreme w eather events more likely. Thus, a key insight for food security interventions in Latin America comes from the vast 
body of international experience in dealing with risky environments, particularly in Africa ${ }^{45,46}$.

Since the 1990s, the development community has realized the importance of linking relief and development activities. Responses to emergencies, obviously, must assist in meeting the immediate short-term needs of those affected. But under certain conditions, some responses (e.g. international food aid) can sabotage longer-term development by weakening local markets, reducing farmer incentives, and/or creating dependencies among the poor. If responses to emergencies can be developed in a way that improves the functioning of local markets, diversifies household livelihoods, and increases household incomes and assets, then relief efforts can be supportive of longer-term development. For example, a well-oriented food-for-work program could improve local infrastructure (e.g., roads, marketplaces, schools) while at the same time provide food support to those in need. Households with expanded livelihoods living in communities with better infrastructure would be able to better withstand future shocks, improving the success of, or even reducing the need for, subsequent relief efforts ${ }^{15}$.

These insights grow out of a framework, known as the "relief to development" continuum, in which intervention activities could be classified as either relief, rehabilitation, or development ${ }^{19}$. Or, using the livelihood framework, activities on this continuum ranged from livelihood provisioning (e.g., supplementary and therapeutic feeding) to livelihood protection (for instance distribution of seeds and tools) to livelihood promotion (e.g., small enterprise development).

This framework has been critiqued for assumptions that shocks are based on discrete, short-term events or that intervention activities necessarily proceed in a linear fashion ${ }^{19}$. How ever, political crises or conflicts, as opposed to weather events, can drag on for long periods of time. And, in some places, components of relief, rehabilitation, and development are all in operation simultaneously. In an area with repeated weather or economic disturbances, today's setting after a problem has occurred is also a setting before the next problem arrives. A recent policy document developed for the US Agency for International Development (USAID) recognizes the non-linearity of responses to problems by suggesting a framew ork for relief and development that explicitly considers the post-shock and pre-shock periods as appropriate times for both relief and development-style interventions ${ }^{21}$. FAO's " twin-track approach" also acknowledges that efforts to improve long-term food security will need to happen at the same time as interventions to address immediate food requirements ${ }^{47}$.

A key aspect of programming, then, is to recognize the elements of vulnerability that many households face and to develop responses to improve their livelihood situation so that they are better able to confront the next emergency. As Webb and Rogers state, "emergency responses should seek as soon as possible to define, not exit strategies, but asset strategies" ${ }^{48}$. In this light, so-called "safety net" interventions - used to keep individuals and households from falling below a deprivation threshold - are not just relief efforts, but essential to development programming ${ }^{21}$. Large-scale, stable, government-funded social protection programs, like Mexico's Progresa/ Oportunidades ${ }^{34}$, Brazil's Bolsa Família27,36, or Nicaragua's Red de Proteccion Social ${ }^{35}$ build asset levels of participants and enable them to cushion against future shocks.

\section{Develop interventions to meet problems in specific contexts}

In a detailed analysis of seven case studies in the Great Lakes region of East and Central Africa on emergencies and humanitarian response, Levine and Chastre found that, " many, if not most, food security interventions failed to address the needs of people affected by crises" 24 . They found that many relief agencies used the same narrow range of responses, even though they were not designed for that region. In many cases, responses 
dealt with symptoms and not causes. In some situations, food was given out where it was abundant, or seeds were given to people who did not need them ${ }^{24}$. Implementing the wrong response is not only wasteful of precious aid resources, but it can cause negative outcomes, such as weakened food markets, or reduced production incentives. Recent analysis and discussions supported by the Overseas Development Institute have called for improvements in food security responses employed in emergency situations ${ }^{24,31,49}$. Strengthening of needs assessments and increasing the flexibility and range of intervention options are key elements.

As with emergencies, efforts to reduce chronic food insecurity should be tailored to the problems at hand. This raises the importance of needs assessments and problem diagnoses; food insecurity information systems should be central to this endeavor. There have been substantial developments in this over the last decade. The experience-based household food security indicator that was originally developed in the U.S. has been adapted in a number of countries ${ }^{50}$. This indicator was developed to monitor national or sub-national prevalence of household food insecurity over time. Although useful for this purpose, it does not provide insights into the causal mechanisms underlying a problem, so it is of limited value in planning interventions in specific contexts. How ever, there have been other impressive developments in food insecurity information systems that allow for the monitoring of household livelihoods, vulnerability to particular shocks, and potential outcomes. For example, the World Food Program has a Vulnerability Assessment and Mapping (VAM) system with household surveys in a number of Sub-Saharan Countries ${ }^{51}$. The Famine and Early Warning System Network, is a network of food security information systems based on baseline analyses of household livelihoods ${ }^{11}$. Save the Children's Household Economy A pproach relies on livelihood assessments for different wealth groups in different agro-ecologic zones in a country ${ }^{12}$. The richness of the household information in all these systems allows for a diagnosis not only of which households are likely to be affected by a shock, but also which aspects of their livelihoods are to be at risk, to what extent will they be affected, and the types of magnitudes of solutions that will be needed.

\section{Pay attention to over-consumption while addressing food insecurity}

Analogous to the importance of considering long-term development while intervening on short-term solutions to food deprivation, it may be prudent to develop strategies to confront food insecurity that do not lead to over-consumption and the problems of overweight. This may be of particular concern for middle income countries, like many in Latin America, that are already showing obesity prevalence rates of serious concern (Table 1 ). Insights from high-income countries with high rates of obesity and overweight may be of value in this area.

In the U.S., there has been substantial work of late on approaches that seek to change the physical or social environment in which individuals live. Environmental approaches to the obesity problem have garnered favor, in part because the problem is so widespread that individual solutions are not likely to be costeffective, and in part because changes in the environment (as opposed to genetic structure) are a logical explanation for the dramatic increase in the problem. Environmental determinants of food consumption and physical activity and interventions to address them have been suggested for children in schools, adults at work sites, and for low-income communities to improve access to healthier foods or opportunities for physical activity ${ }^{52}$. The U.S. government, via the Department of Agriculture (USDA), has promoted research on how the Food Stamp Program, its largest food insecurity intervention, can do more to address the obesity problem $^{53}$ and, although still relatively low, funding 
for the Food Stamp Nutrition Education Program has been dramatically increased ${ }^{54}$. USDA, based on expert consultation, has developed historic changes in the food package it offers to low-income women and children, in part, to address the obesity problem ${ }^{55}$.

One challenge for program and policy work in this area is the tension between private and public concerns. Since health outcomes related to obesity are costly and often paid by government, it is in the public's interest to develop environmental interventions which reduce exposure of the population, either through advertising or availability, to unhealthy foods. This argument is particularly persuasive with respect to children, since life long food habits are developed early and obesity rates have skyrocketed in this group. This approach runs against the interests of many producers in the food industry who do not want to see restraints on their marketing activities. The political and legal battles that have ensued from this tension have been well documented in the U.S. context ${ }^{56,57}$. It would not be surprising to see similar battles take hold in middle-income countries.

\section{Enhance community-based participatory actions}

An important aspect of efforts to reduce food insecurity is not just what specific intervention components are employed, but also how they are developed and implemented. Participatory approaches to development and poverty reduction rely on community involvement in assessment, program design, and evaluation. Although this type of approach is not new, several recent developments should raise the motivation for its adoption. First, research has demonstrated the potential of participatory approaches to increase program effectiveness. Community members understand local conditions better than outside program developers and can thus develop interventions that are more likely to succeed in their areas, in part because programs can be better targeted, more realistically designed, and produce outcomes closer to the concerns of community residents. For example, analysis of the experience of a public works project in South Africa, demonstrated that community participation lowered the cost of creating employment and transferring funds to poor individuals ${ }^{58}$.

Second, participatory-based programs have the potential to develop local capacities beyond the specific objectives of a particular program. In contrast to top-down approaches which tend to stifle local initiative, the empowering nature of working together to assess and develop solutions to a problem may be useful for confronting other challenges that communities face. There has been increasing recognition of the importance of a rights-based approach in reducing food insecurity and the need for active participation of all stakeholders in policy development. Thus, asserting one's rights requires a form of empowerment, which may be facilitated by participatory initiatives. FAO has taken a key role on this rights-based approach by coordinating the development of guidelines on the right to food in the context of national food security ${ }^{59}$, and by identifying ways for this to be practically implemented at the national level ${ }^{60}$.

Finally, detailed methodologies now exist for involving community groups in the assessment and design of interventions. For example, work in Tanzania supported by the International Fund for Agricultural Development and the Belgian Survival Fund has led to development of a manual for a "bottom-up-approach" to food security interventions ${ }^{61}$. The manual provides step-by-step procedures on how to involve community members in assessment, program design, implementation, and evaluation. The ready availability of this type of methodology, evidence of improved program effectiveness of participatory approaches, and their importance for empowerment and promotion of the right to food all argue for increasing program activity in this area. 


\section{REFERE N C E S}

1. Food and Agriculture Organization. The state of food insecurity in the world. Eradicating world hunger: taking stock ten years after the W orld Food Summit. Rome: FAO; 2006.

2. The World Bank. Data downloaded from world development indicators quick query. [cited 2007 May 25]. Available from: <http://ddp-ext. worldbank.org/ext /DDPQQ/member.do?method= getM embers\&userid =1\&queryld =135>.

3. World Health Organization. WHO statistical information system: core health indicators. [cited 2007 May 30]. Available from: <http://www.who. int/w hosis /database/core/core_select.cfm>.

4. Food and Agriculture Organization. Rome declaration on world food security. World Food Summit. Rome: FAO;1996.

5. Brown L, Gentilini U. The role of food-based safety nets in helping vulnerable households manage food insecurity: research paper no 2006/111. Washington (DC): UNU-WIDER; 2006.

6. Sen A. Poverty and famines. An essay on entitlement and deprivation. Oxford: Clarendon Press; 1981.

7. Reutlinger S, van Holst Pellekaan J. Poverty and hunger: issues and options for food security in developing countries. WB Policy Study no 9275. Washington (DC): The World Bank; 1986.

8. The World Bank. World development report 2000/ 2001. Attacking poverty. Oxford: Oxford University Press; 2001.

9. Chambers R. Vulnerability, coping, and policy. IDS Bulletin. 1989; 20(2):1-7.

10. Maxwell S, Frankenberger T. Household food security: concepts, indicators, measurement. A technical review. Rome: Unicef; 1992.

11. US Agency for International Development - Femine and Early Warning System. FEWS NET'S approach to livelihoods-based food security analysis. [cited 2007 Jun 3]. Available from: <http://www.fews. net/ livelihoods/FNLBroch_en.pdf >.

12. Seaman J, Clarke P, Boudreau T, Holt J. The household economy approach: a resource manual for practitioners. London: Save the Children; 2000.

13. World Food Programme. Emergency food security assessment handbook. Rome: WFP; 2005.

14. Barrett C. Food aid as part of a coherent strategy to advance food security objectives. ESA Working Paper no 06-09. Rome: FAO; 2006.

15. Devereux S. Policy options for increasing the contribution of social protection to food security. Sussex: Institute of Development Studies; 2003.
16. Webb P, Harinarayan A. A measure of uncertainty: The nature of vulnerability and its relationship to malnutrition. Disasters. 1999; 23(4):292-305.

17. Devereux S. Livelihood insecurity and social protection: a re-emerging issue in rural development. Dev Policy Rev. 2001; 19(4):507-19.

18. Lovendal CR, Knowles M. Tomorrow's hunger: a framework for analyzing vulnerability to food insecurity. ESA working paper no 05-07. Rome: FAO; 2005.

19. CARE. Managing risk, improving livelihoods: Program guidelines for conditions of chronic vulnerability. 2nd ed. Nairobi: CARE; 2003.

20. Von Braun J, Bouis H, Kumar S, Pandya-Lorch R. Improving food security of the poor: concept, policy, and programs. Washington (DC): International Food Policy Research Institute; 1992.

21. Haddad L, Frankenberger R. Integrating relief and development to accelerate reductions in food insecurity in shock-prone areas. Occasional paper no 2. Washington (DC): US Agency for International Development; 2003.

22. Allen L. Interventions for micronutrient deficiency control in developing countries: past present and future. J Nutr. 2003; 133:3875S-8S.

23. World Bank. International Food Policy Research Institute. Agriculture and achieving the Millennium Development Goals. Report no 32729-GLB. Washington (DC): World Bank; 2006.

24. Levine $S$, Chastre $C$, et al. Missing the point: an analysis of food security interventions in the Great Lakes: Humanitarian Practice Network paper no 47. London: Overseas Development Institute; 2004.

25. CARE. The aftermath of Hurricane Mitch: how CARE is responding. Relief Web Dec; 1999 [cited 2007 Jun 6]. Available from: <http://www. reliefweb.int/rw/rwb.nsf/0/daa40ac7066f 83c085256810007a991e? OpenDocument\&Click $=>$.

26. Low J, Arimond M, Osman N, Cunguara B, Zano F, Tschirley D. A food-based approach introducing orange-fleshed sweet potatoes increased vitamin A intake and serum retinol concentrations in young children in rural M ozambique. J Nutr. 2007; 137: 1320-7.

27. Paes-Sousa R, Vaitsman J. Síntese das pesquisas de avaliação de programas sociais do MDS. Cadernos de Estudos: Desenvolvimento Social em Debate, Número 5. Brasília: M inistério do Desenvolvimento Social e Combate à Fome; 2007.

28. Ministry of Social Development and Fight against Hunger. Data Brazil: Programs of the Ministry of Social Development and Fight against Hunger, 2004-2005. Brasília: MDS; 2007. 
29. Baffes J, Gorter H. Experience with decoupling agricultural support. In: Aksoy MA, Beghin JC, editors. Global agricultural trade and developing countries. Washington (DC): The World Bank; 2005.

30. Rogers BL, Coates J. Food-based safety nets and related programs. Food policy and applied nutrition program discussion paper $\mathrm{n}-12$. Boston: Tufts University; 2002.

31. Harvey P. Cash and vouchers in emergencies. Humanitarian Practice Group discussion paper. London: Overseas Development Institute; 2005.

32. Kamaluddin S. Lender with a mission: Bangladesh's Grameen Bank targets poorest of poor. Far East Econ Ver. 1993; 156:38-40.

33. Consultative Group to Assist the Poor. Scaling up poverty reduction: case studies in microfinance. Washington (DC): The World Bank; 2004.

34. Skoufias E. PROGRESA and its impacts on the welfare of rural households in Mexico. Research report 139. Washington (DC): International Food Policy Research Institute; 2005.

35. Maluccio J, Flores R. Impact evaluation of a conditional cash transfer program: the Nicaraguan Red de Proteccion Social. Washington (DC): IFPRI; 2004.

36. FAO. Fome zero: lições principais [Documento de trabalho]. Santiago: Escritório regional da FAO para America Latina e o Caribe; 2006.

37. World Bank. Shocks and social protection: lessons from the Central American coffee crisis. Volume I: Synthesis of findings and implications for policy. Washington (DC): World Bank; 2005.

38. Jennings J, Peri A. Activities to promote mother and child well-being in CARE's PL480 Title II integrated programs: a closer look at the Honduras \& Mozambique programs. Atlanta: CARE; 2002.

39. Food and Nutrition Service. Nutrition education in FNS: a coordinated approach for promoting healthy behaviors. A Report to Congress. Washington (DC): U.S. Department of Agriculture; 2002.

40. U.S. General Accounting Office. Early intervention: federal investments like WIC can produce savings. GAO/HRD-92-18. Washington (DC): GAO; 1992.

41. Chandler A-M K, Walker SP, Connolly K, GranthamMcGregor SM. School breakfast improves verbal fluency in undernourished Jamaican children. J Nutr. 1995; 125:894-900.

42. Bhattacharya J, Currie J, Haider SJ. Evaluating the impact of school nutrition programs. Final report.
Publication \# E-FAN-04-008. Washington (DC): USDA; 2004 [cited 2007 Jun 7]. Available from: <http://www.ers.usda.gov/Publications/ EFAN04008/>.

43. Fraker T. The effects of food stamps on food consumption: a review of the literature," Washington (DC): Mathematica Policy Research; 1990.

44. World Food Programme. Where we work - Ethiopia. [cited 2007 Jun 5]. Available from: <http://www. w fp.org/country_brief/indexcountry.asp? country $=231>$.

45. Mattinen H, Ogden K. Cash-based interventions: lessons from Southern Somalia. Disasters. 2006; 30(3):297-315.

46. Schnell C. Strengthening local governance to enhance the impact and sustainability of food \& livelihood security interventions: case studies from CARE Honduras and Peru Title Il programs. Atlanta: CARE; 2002.

47. Food and Agriculture Organization. Anti-Hunger Programme. A twin-track approach to hunger reduction: priorities for national and international action. Rome: FAO; 2003.

48. Webb P, Rogers B. Addressing the "In" in food insecurity. Occasional paper $\mathrm{n}-1$. Washington (DC): US Agency for International Development; 2003.

49. Overseas Development Institute. 'Getting the point': improving food security interventions in emergencies. Notes from a meeting hosted by ODI, June, 2005 [cited $2007 \mathrm{M}$ ay 25]. Available from: $<$ tttp://www.odi.org.uk/HPG/meetings/Getting_ the_Point.pdf>.

50. Melgar-Quinonez HR, Hackett M. A medida da segurança alimentar: a experiência mundial. Rev Nutr. 2008; 21(Supl). [no prelo].

51. World Food Programme. VAM Standard Analytic Framew ork: Role and Objectives of VAM Activities to Support WFP Food-Oriented Interventions. Rome: World Food Programme; 2002.

52. Booth SL, Sallis JF, Ritenbaugh C, et al. Environmental and societal factors affect food choice and physical activity: Rationale, influences, and leverage points. Nutr Reviews. 2001; 59(3 Pt 2):S21-S39; discussion S57-65.

53. Guthrie JF, Frazão B, Andrews M, Smallwood D. Improving food choices - Can food stamps do more? Amber Waves 2007; 5(2): 22-28 [cited 2007 June 3]. Available from: <http://www.ers.usda.gov/ a mberwaves/april0 $7 /$ features/improving foodchoices.htm>. 
54. Food and Nutrition Service. Nutrition program facts: Food stamp nutrition education. US Department of Agriculture, 2006 [cited 2007 Jun 6]. Available from: <http://www.fns.usda.gov/fsp/nutrition education/FSNE-Factsheet-2006.pdf>.

55. Committee to Review the WIC Food Packages. Institute of Medicine. WIC food packages: time for a change. Washington (DC): National Academy Press; 2005.

56. Nestle, M. Food Politics: how the food industry influences nutrition and health. Berkeley: University of California Press; 2002.

57. Brownell KD, Horgen KB. Food fight: the inside story of the food industry, America's obesity crisis, and what we can do about it. Chicago (IL): Contemporary Books; 2004.

58. Hoddinott J, Adato M, Besley T, Haddad L. Participation and poverty reduction: issues, theory, and new evidence from South Africa. FCND discussion paper $n \cong$ 98. Washington (DC): International Food Policy Research Institute; 2001.

59. Food and Agriculture Organization. Voluntary guidelines to support the progressive realization of the right to adequate food in the context of national food security. Rome: FAO; 2005.

60. Food and Agriculture Organization. The right to food in practice: implementation at the national level. Rome: FAO; 2006.

61. Beerlandt H, Huysman S. Analysis of target groups. Manual for bottom-up-approach in food security interventions. International Fund for Agricultural Development; 1999 [cited 2007 M ay 15]. Available from: <http://www.ifad.org/gender/tools/hfs/ bsfpub/manual_toc.htm>.

Received on: 12/6/2007

Final version resubmitted on: 23/4/2008

Approved on: 26/5/2008 
